\title{
PENGGUNAAN MEDIA PEMBELAJARAN ALTERNATIF SEBAGAI MITIGASI DAN ADAPTASI PADA MASA PANDEMI COVID-19
}

\author{
Tania Intan, Nany Ismail, Vincentia Tri Handayani \\ 1,2,3Program Studi Sastra Perancis, Universitas Padjadjaran \\ Email: ${ }^{1}$ tania.intan@unpad.ac.id, ${ }^{2 n a n y . i s m a i l @ u n p a d . a c . i d, ~}{ }^{3}$ v.tri@unpad.ac.id
}

\begin{abstract}
Abstrak
Media dan metode belajar merupakan unsur pembelajaran yang dapat memengaruhi motivasi belajar sehingga berdampak pada kualitas hasil pendidikan. Situasi pandemi Covid-19 pada tahun 2020 menyebabkan diberlakukannya kebijakan pembatasan kegiatan belajar mengajar tatap muka dan mendukung pada pembelajaran daring. Realitasnya, kegiatan virtual tidak selalu menyenangkan dan mudah dilakukan, karena lama-kelamaan siswa dan pengajar merasa jenuh dan bahkan kerap mengalami kesulitan teknis dalam memanfaatkan sarana dan teknologi. Tim PPM yang bekerja sama dengan mahasiswa peserta Kuliah Kerja Nyata Universitas Padjadjaran mencoba menemukan solusi permasalahan tersebut. Menyikapi permasalahan yang disampaikan oleh subjek/mitra kegiatan sebagai representasi pengajar dari berbagai tingkatan, tim PPM dan mahasiswa peserta KKN merancang sebuah media pembelajaran yang mudah digunakan dengan tujuan untuk menunjang kegiatan belajar mengajar agar menjadi lebih menyenangkan, interaktif, dan kolaboratif. Metode PPM yang diterapkan adalah sosialisasi pemanfaatan situs web "Virtual Edu Guide". Selain menambah performa, pengetahuan, dan keterampilan subjek/mitra, indikator keberhasilan yang ditunjukkan program ini adalah jumlah kunjungan pada situs sebanyak 194 kali setelah program berjalan selama lima hari.
\end{abstract}

Kata-kata kunci: media pembelajaran, mitigasi dan adaptasi, masa pandemi

\begin{abstract}
Media and methods are elements of learning that can affect learning motivation so that it has an impact on the quality of educational outcomes. The Covid-19 pandemic situation in 2020 led to a policy of limiting face-to-face teaching and learning activities and supporting online learning. In reality, virtual activities are not always fun and not always successful, because over time the students and teachers feel bored and even often experience technical difficulties in utilizing facilities and technology. The PPM team in collaboration with students participating in the KKN at Padjadjaran University tried to find solutions to these problems. Responding to the problems raised by the subject/activity partners as a representation of teachers from various levels, the PPM team and KKN participant students designed a learning media to support teaching and learning activities to be more fun, interactive, and collaborative. The PPM method used is the socialization of the use of the "Virtual Edu Guide" website. Besides being able to increase the knowledge and skills of subjects/partners, the indicator of success shown by this program is the number of visits to the site as many as 194 times after the program runs for five days.
\end{abstract}

Keywords: learning media, mitigation, adaptation, pandemic

\section{PENDAHULUAN}

Pandemi Covid-19 telah memengaruhi setiap sendi kehidupan manusia di dunia (Chaerani, 2020), termasuk dalam bidang pendidikan. Untuk memutus mata rantai penyebaran virus covid-19, setiap orang pun diwajibkan untuk tetap tinggal di rumah dan melakukan Social Distancing, sehingga konsep ruang dan gerak menjadi semakin sempit dan terbatas. Demikian pula halnya dengan konteks pendidikan, di mana para pengajar maupun pelajar harus beradaptasi dan mulai bertransisi agar dapat bertahan dan kegiatan pembelajaran tetap berjalan. Kegiatan belajar mengajar, seperti bekerja, diliburkan atau dilakukan dari rumah dengan tujuan mengurangi potensi penularan virus Covid-19 (Siahaan, 2020: 1). 
Belajar dari rumah menjadi keharusan karena sekolah berpotensi menjadi tempat berkumpulnya siswa dan guru untuk melaksanakan pembelajaran. Arifa (2020: 14) (2020: 14) menjelaskan bahwa "Kebijakan belajar di rumah dilaksanakan dengan tetap melibatkan pendidik dan peserta didik melalui Pembelajaran Jarak Jauh). Kegiatan daring ini telah dilaksanakan di Indonesia sejak pertengahan bulan Maret 2020 dan mungkin akan terus diperpanjang dengan mempertimbangkan situasi dan kondisi di masing-masing daerah.

Penelitian terhadap upaya adaptasi sosial mahasiswa terhadap hambatan dalam pembelajaran secara daring dan pengaruhnya pada aspek kehidupan keluarga dilakukan oleh Dulkiah dkk (2020). Kajian dampak pandemi terhadap sektor pendidikan juga dilakukan Aji (2020) yang meneliti fenomena ditutupnya (secara sementara) sejumlah besar lembaga pendidikan sebagai upaya menahan penyebaran pandemi. Terjadi gangguan dalam proses belajar langsung di antara siswa dan guru serta berbagai program pembelajaran yang menyebabkan meningkatnya beban psikologis terutama pada orang tua serta menurunnya kualitas keterampilan siswa. Kajian Karwati (2014) yang dilaksanakan sebelum pandemi pun menyatakan bahwa terdapat perbedaan hasil dari pembelajaran tatap muka (face-to-face) dengan pembelajaran jarak jauh. Hal ini menunjukkan adanya permasalahan tersendiri dalam pengelolaan pembelajaran daring yang harus diatasi.

Siahaan (2020: 1) menjelaskan bahwa permasalahan muncul baik pada siswa maupun guru, seperti tugas yang diberikan menjadi lebih banyak. Kendala lainnya adalah akses informasi yang terkendala oleh sinyal dan kondisi gadget yang terbatas. Kejenuhan belajar pada masa pandemi Covid-19 juga menjadi masalah tersendiri sebagaimana dijelaskan Ningsih (2020: 1) bahwa siswa mengalami kesulitan dalam memahami materi karena kurangnya variasi metode yang digunakan guru. Selain itu, kejenuhan muncul karena tugas yang terlalu banyak, tidak adanya teman belajar karena pembelajaran jarak jauh, berkurangnya konsentrasi belajar karena terlalu lama menatap layar handphone/laptop, keterbatasan kuota, dan lingkungan rumah yang tidak mendukung suasana belajar.

Bila terus dibiarkan, kejenuhan belajar akan dapat berdampak pada siswa untuk keberlangsungan pendidikannya. Menurut Hidayat, secara psikologis, perilaku yang ditunjukkan orang yang mengalami kejenuhan ada mudah marah, mudah terluka, dan mudah frustasi (Pawicara, 2020: 30). Sementara itu, Napitupulu (2020: 23) mengemukakan bahwa metode pembelajaran jarak jauh yang diselenggarakan pada masa pandemi ini tidak sepenuhnya memuaskan bagi pembelajar dan pengajar. Tantangan dalam pembelajaran daring meliputi teknik pengajaran, media, perangkat komputer, koneksi internet, dan keterampilan mengoperasikan teknologi digital (Hudaa, 2020: 375).

Untuk mengatasi permasalahan tersebut, diperlukan variasi metode pembelajaran dan media, sebagaimana dinyatakan Sari dan Mayrita (2020). Variasi ini disesuaikan dengan penguasaan dan keterampilan pengajar dalam menggunakan teknologi informasi, seperti platform yang umum seperti email, Zoom Meeting, Google Classroom, Whatsapp, dan Youtube. Selain platform yang berbeda, variasi juga perlu diberlakukan dalam pemberian jenis tugas. Hal tersebut relevan dengan pernyataan Nikmah (2020: 45), bahwa diperlukan kesungguhan dan keseriusan pengajar dalam menyiapkan strategi pembelajaran daring, yang dilengkapi dengan media dan metode pembelajaran yang sesuai.

Interaksi merupakan unsur penting namun kerap terlupakan dalam pembelajaran jarak jauh atau daring. Aplikasi Google Classroom yang familiar di kalangan akademisi sangat bermanfaat sebagai media untuk membagikan materi, tugas, atau penilaian, namun belum ada fitur video call yang memungkinkan terjadinya komunikasi dua arah (Hudaa, 2020: 376). Aplikasi lainnya, Zoom dan Google Meet menyediakan ruang pertemuan guru dan 
murid namun ketidakstabilan jaringan internet kerap menjadi permasalahan tersendiri.

Bagaimana pun juga pembelajaran tetap harus diselenggarakan. Menurut Gunawan dalam Herliandry (2020: 67) hal ini mengharuskan pendidik dan peserta didik berinteraksi memanfaatkan berbagai platform yang tersedia seperti aplikasi, website, jejaring sosial, maupun learning management system.

Sebagai bagian dari Tri Dharma Perguruan Tinggi, tim yang terdiri dari tiga dosen Program Studi Sastra Perancis Universitas Padjadjaran merancang kegiatan Pengabdian Pada Masyarakat (PPM) yang dilakukan secara integratif bersama dengan program $\mathrm{KKN}$ Virtual. Kegiatan yang melibatkan lima mahasiswa dari program studi yang beragam ini dilaksanakan selama bulan Januari dan Februari 2021.

Permasalahan yang dirumuskan sebagai fokus kegiatan PPM adalah kebutuhan para pengajar dan pembelajar untuk menemukan metode dan media pembelajaran daring yang menarik, integratif, dan kolaboratif. Dengan tujuan membantu memecahkan permasalahan tersebut, tim menyusun berbagai langkah solutif dengan maksud meningkatkan potensi dan kualitas pembelajaran di masa pandemi Covid-19.

\section{METODE PELAKSANAAN}

Dengan mengikuti instruksi pemerintah yang ditegaskan kembali oleh pimpinan Universitas Padjadjaran, maka kegiatan PPMKKN dilaksanakan secara daring di daerah tempat tinggal masing-masing, baik tim pelaksana, mahasiswa, maupun para subjek sebagai pihak yang menjadi sasaran kegiatan. Subjek atau mitra kegiatan ini dipilih dari warga masyarakat dari kalangan pendidik yang dikenal oleh tim PPM-KKN. Dari kuesioner yang dibagikan kepada sekitar sepuluh subjek pada tahap persiapan, dapat diketahui permasalahan umum yaitu tentang kebutuhan akan metode dan materi pembelajaran yang interaktif dan kolaboratif.

Dalam prosesnya, kegiatan dilakukan tanpa tatap muka langsung dengan cara memanfaatkan teknologi informasi dan aplikasi seperti WhatsApp Group untuk berkomunikasi, Trello untuk mengoordinasikan tugas dan langkah kegiatan, Google Meet untuk mendiskusikan program antarpelaksana kegiatan, serta Zoom Meeting untuk sosialisasi pemanfaatan situs web di antara tim, mahasiswa, dan subjek.

Secara keseluruhan ada tiga tahap besar yaitu persiapan, pelaksanaan, dan evaluasi yang dilakukan selama bulan Januari dan Februari 2021. Tema utama yang diusung untuk tim PPM menyesuaikan dengan permasalahan bersama yang dihadapi masyarakat yaitu "Penguatan Peran Warga Masyarakat dalam Mitigasi dan Adaptasi Menghadapi Pandemi Covid-19" yang menjadi payung besar bagi empat subtema yang dieksplorasi yaitu: pendidikan, ekonomikewirausahaan, kesehatan, dan sosial budaya. Keempatnya dilakukan secara bersama-sama oleh tim pelaksana PPM dan kelompokkelompok mahasiswa.

Tahap persiapan kegiatan PPM-KKN (5 - 13 Januari 2021) diisi dengan pembagian tugas dan peran masing-masing serta timeline kegiatan. Pada tahap ini juga dibahas identifikasi mitra yang sesuai dengan tema, sumber daya, serta analisis SWOT terhadap kondisi selama kegiatan berlangsung. Selanjutnya dilakukan penyusunan dan distribusi kuesioner melalui media sosial kepada subjek.

Tahap pelaksanaan (13 - 31 Januari 2021) dimulai dengan pembahasan hasil kuesioner untuk menemukan permasalahan para subjek yang selanjutnya menjadi fokus program kegiatan. Tahap evaluasi dan tindak lanjut (3 15 Februari 2021) berisi pembahasan mengenai hasil kegiatan dengan subjek serta dokumentasi saran dan aspirasi mereka tentang permasalahan. Bagian terakhir adalah penyusunan laporan.

\section{HASIL DAN PEMBAHASAN}

Kegiatan PPM-KKN ini berfokus pada pembuatan situs web "Virtual Education Guide" yang berisi beragam $e$-book, aplikasi, dan media alternatif seperti Google Jambord, Kahoot, Quizz, dan sebagainya, yang dapat digunakan 
pengajar dan pembelajar di masa pandemi. Sosialisasi dan penyebaran situs web selanjutnya dilakukan melalui sosial masingmasing. Tautan situs web tersebut adalah sebagai

berikut:

(https://virtualeduguide.wixsite.com/mysite).

Setelah menyiapkan instrumen untuk implementasi, tim bersama mahasiswa menyebarkan broadcast message yang menerakan link website "Virtual Education Guide" kepada mitra. Mereka kemudian menyebarkan kembali broadcast message tersebut kepada sesama tenaga pengajar dan peserta didik melalui grup-grup yang mereka miliki. Sebagai bukti pelaksanaan, mitra mengirimkan hasil tangkap layar saat menyebarkan informasi tersebut.

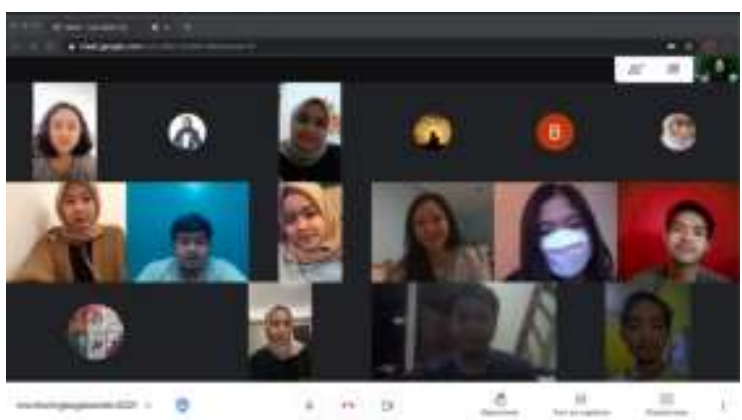

Gambar 1. Sosialisasi pada Mitra

Kegiatan KKN dilakukan dengan membuat sebuah program berupa penyuluhan yang dilakukan menggunakan media website. Website tersebut diberi nama "Virtual Education Guide", yang memuat artikel-artikel tentang media pembelajaran yang dapat digunakan oleh pengajar selama kegiatan belajar-mengajar (KBM) daring. Di dalamnya, terdapat penjelasan mengenai media pembelajaran, link video tutorial penggunaan media pembelajaran, serta link media pembelajaran tersebut. Selain itu, di laman awal website terdapat video pengantar dari anggota kelompok yang berisikan kalimat pengantar dan maksud dari pembuatan website tersebut.

Pemilihan website sebagai media penyuluhan didasari oleh hasil diskusi seluruh anggota kelompok, meskipun hasil kuesioner menunjukkan bahwa webinar merupakan bentuk program KKN yang paling banyak dipilih oleh mitra. Hal ini dikarenakan keterbatasan waktu dan sumber daya, sehingga dibuatlah opsi baru yang merupakan jalan tengah, yaitu pembuatan website.

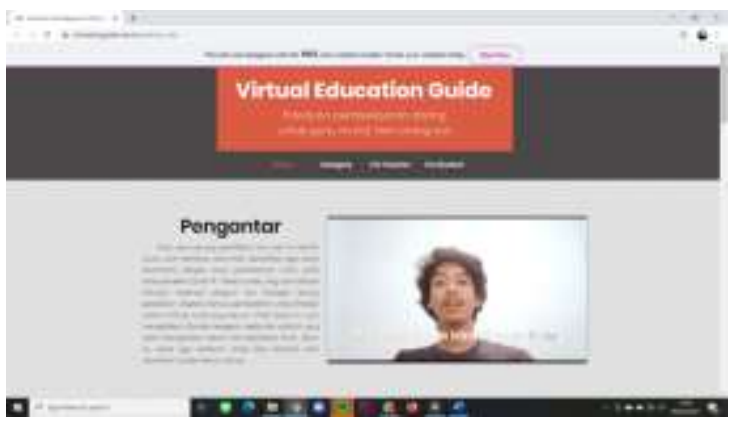

Gambar 2. Tampilan Situs web

Di dalam website, terdapat video interaktif singkat berdurasi 2 menit yang menyajikan informasi terkait latar belakang pembuatan website dan pihak-pihak yang terlibat. Subjek selain memberi masukan melalui kuesioner dan wawancara juga memberi ulasan terhadap materi situs web yang sedang dikerjakan. Subjek juga berperan menyebarkan situs tersebut pada rekan-rekannya agar dapat menjadi penyelesaian masalah dari menurunnya motivasi belajar-mengajar secara online.

Publik yang terutama menjadi sasaran pengguna web ini adalah pengajar dan pembelajar. Pengajar dapat mengakses kategori "For Teacher" sedangkan kategori "For Student" ditujukan pada siswa. Orang tua siswa juga dapat mengakses situs tersebut untuk mengetahui media pembelajaran dan kemajuan putra dan putri mereka selama KBM daring.

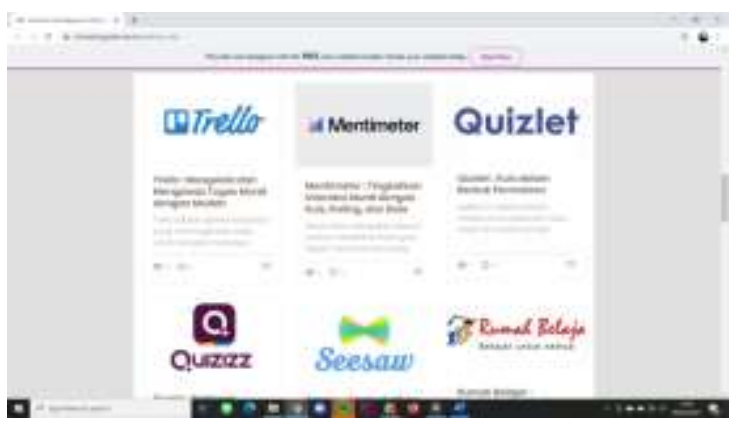


Gambar 3. Berbagai Aplikasi Pembelajaran Alternatif

Program ini dapat disebut berhasil berdasarkan kunjungan pada situs "Virtual Education Guide" sebanyak 194 kali dari tanggal 25 Januari - 1 Februari 2021. Pengunjung berasal dari berbagai daerah di Indonesia, di antaranya Jakarta, Bekasi, Bogor, Semarang, Jogjakarta, Surabaya, dan Surakarta. Selain itu, diketahui sebanyak 184 pengunjung membuka langsung (direct) situs web melalui pemberian link dari tim PPM-KKN maupun dari mitra, dengan menggunakan gadget masing-masing.

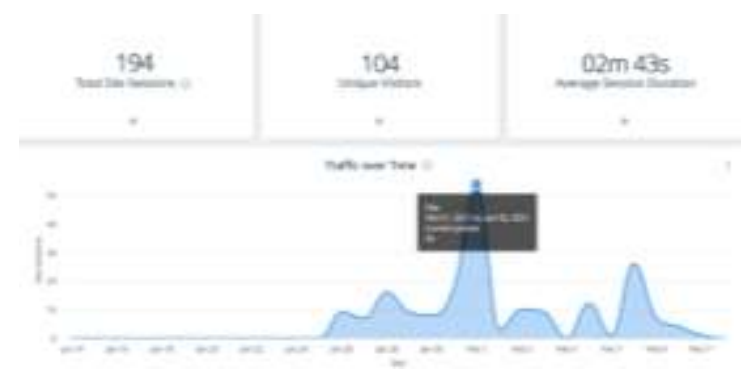

Gambar 4. Traffic Over Time Website

Program tersebut memiliki tindak lanjut berupa pembuatan poster untuk mempromosikan website "Virtual Education Guide" secara lebih luas.

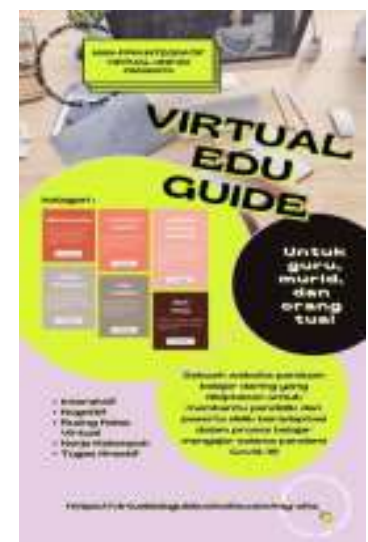

Gambar 5. Poster Website Virtual Education Guide

Poster tersebut disebarkan secara virtual melalui mitra, dan bila memungkinkan, akan ditempel di media informasi sekolah-sekolah yang menjadi lokasi kegiatan PPM-KKN. Poster ini diharapkan dapat meningkatkan kepedulian pengajar dan peserta didik untuk memanfaatkan media alternatif yang interaktif dan kolaboratif tersebut.

Indikator ketercapaian program PPM ini selain capaian jumlah pengunjung situs yang cukup tinggi, juga adalah perubahan kognitif pada pengajar dan peserta didik. Pada umumnya, mereka menggunakan media Zoom Meeting atau Google Meet saja, namun setelah mengetahui situs "Virtual Education Guide", para subjek dapat mengeksplorasi pembelajaran dengan lebih menyenangkan dan variatif. Selain itu, berdasarkan hasil evaluasi, para subjek menyatakan ada peningkatan performa dan semangat belajar siswa yang menjadi tolak ukur keberhasilan program.

\section{KESIMPULAN DAN SARAN \\ Kesimpulan}

Kondisi pandemi yang menuntut pembelajaran dilakukan secara daring menyebabkan permasalahan pada berbagai pihak seperti pengajar, siswa, maupun orang tua siswa. Selain masalah kuota internet, kegiatan belajar mengajar menjadi terbatas dan metode serta media pembelajaran menjadi monoton sehingga siswa menjadi kehilangan semangat belajar.

Website "Virtual Education Guide" dirancang sebagai media pembelajaran alternatif yang berisi artikel-artikel (dan direncanakan akan memuat animasi serta video) sebagai referensi pengajar yang juga dapat diakses oleh siswa dan orang tua. Pemanfaatan situs web sebagai luaran program ini akan terus dipantau kebermanfaatannya pada masyarakat pengguna dan ditingkatkan kualifikasinya agar terus berdampak secara signifikan.

\section{Saran}

Berdasarkan temuan kegiatan pengabdian pada masyarakat yang diperoleh melalui kuesioner terhadap subjek maupun hasil observasi, tim pelaksana menyarankan kepada pihak yang berwenang dalam bidang pendidikan untuk menyelenggarakan pelatihan-pelatihan teknologi informasi dan komunikasi pada para guru. Bila 
memungkinkan, pemerintah juga diharapkan dapat terus mengalokasikan dana untuk mensubsidi kuota internet terutama untuk para siswa dan pengajar yang tidak mampu.

\section{Ucapan Terima Kasih}

Tim pelaksana PPM mengucapkan terima kasih kepada Universitas Padjadjaran yang telah memfasilitasi kegiatan pengabdian kepada masyarakat ini sehingga setiap tahap kegiatan terselenggara dengan baik. Tim juga berterima kasih atas bantuan para mahasiswa peserta KKN yang telah membantu pelaksanaan kegiatan PPM dengan penuh semangat dan kreativitas tinggi. Tim juga menyampaikan apresiasi dan rasa terima kasih para mitra kegiatan sebagai subjek KKN yang telah menyediakan waktu dan tenaga untuk berpartisipasi dalam memperkuat peran warga masyarakat menghadapi pandemi Covid-19.

\section{DAFTAR REFERENSI}

Aji, R. H. S. (2020). Dampak Covid-19 pada Pendidikan di Indonesia: Sekolah, Keterampilan, dan Proses Pembelajaran. Salam: Jurnal Sosial $\mathcal{E}$ Budaya Syar-i, 7(5), 395-402.

Arifa, F. N. (2020). Tantangan Pelaksanaan Kebijakan Belajar dari Rumah dalam Masa Darurat Covid-19. Info Singkat; Kajian Singkat terhadap Isu Aktual dan Strategis, XII(7/I).

Chaerani, D. d. (2020). Pemetaan Usaha Mikro Kecil Menengah (UMKM) pada Masa Pandemi Covid-19 Menggunakan Analisis Media Sosial dalam Upaya Peningkatan Pendapatan. Dharmakarya: Jurnal Aplikasi Ipteks untuk Masyarakat, 9(4), 275-282.

Dulkiah, M. d. (2020). Adaptasi Mahasiswa dalam Penggunaan Media Online sebagai Dampak Wabah Covid-19. Jurnal E-digilib UIN Sunan Gunung Djati.

Herliandry, L. D. N. S., M.E.; Kuswanto, H. (2020). Pembelajaran Pada Masa Pandemi Covid-19. Jurnal Teknologi Pendidikan, 22(1), 65-70.
Hudaa, S. B., Ahmad; Nuryani. (2020). Pemanfaatan Teknologi untuk Pengajaran Bahasa Indonesia di Tengah Pandemi Covid-19. Ranah: Jurnal Kajian Bahasa, 9(2), 374-385.

Karwati, E. (2014). Pengaruh Pembelajaran elektronik (e-learning) terhadap mutu belajar mahasiswa. Jurnal Penelitian Komunikasi, 17(1), 41-54.

Napitupulu, R. M. (2020). Dampak pandemi Covid-19 terhadap kepuasan pembelajaran jarak jauh. Jurnal Inovasi Teknologi Pendidikan, $7(1), 23-33$.

Nikmah, N. (2020). Strategi Pembelajaran Daring pada Masa Pandemi Covid 19 (Studi di Jurusan Akuntansi Politeknik Negeri Banjarmasin). Dialektik, 2(2), 45-51.

Ningsih, L. K. (2020). Analisis Pembelajaran Daring terhadap Kejenuhan Belajar Mahasiswa Tadris Biologi IAIN Jember di Tengah Pandemi Covid-19. Alveoli: Jurnal Pendidikan Biologi, 1(1), 29-38.

Pawicara, R., \& Conilie, M. (2020). Analisis Pembelajaran Daring terhadap Kejenuhan Belajar Mahasiswa Tadris Biologi IAIN Jember di Tengah Pandemi Covid-19. Alveoli: Jurnal Pendidikan Biologi, 1(1), 29-38. doi:https:// doi.org/10.35719/alveol i.v1i1.7

Sari, A. P. I. d. M., H. (2020). Variasi Pembelajaran Bahasa Indonesia Mahasiswa Universitas Bina Darma di Masa Pandemi. Jurnal Ilmiah Bina Edukasi, 13(2), 66-75.

Siahaan, M. (2020). Dampak Pandemi Covid-19 terhadap Dunia Pendidikan. Jurnal Kajian Ilmiah (JKI, 1, 1-3. 